\title{
Parch srebrzysty (Helminthosporium solani) - objawy i zwalczanie
}

\author{
Silver scab (Helminthosporium solani) - symptoms and control
}

\author{
Jerzy Osowski®凶, Janusz Urbanowicz ${ }^{\oplus}$
}

Instytut Hodowli i Aklimatyzacji Roślin - PIB, Radzików,

Zakład Nasiennictwa i Ochrony Ziemniaka, 76-009 Bonin 3

$\triangle$ e-mail: j.osowski@ihar.edu.pl

\begin{abstract}
Zwiększające się od lat zapotrzebowanie rynku i konsumentów na produkty przetworzone z ziemniaków oraz popyt na ziemniaki myte i paczkowane sprawiają, że jakość bulw (gładka skórka, brak oznak chorób) oraz przydatność do przetwórstwa mają duże znaczenie. Taka tendencja powoduje, że każdy patogen przyczyniający się do uszkodzenia skórki nabiera znaczenia ekonomicznego. Jednym z nich jest grzyb Helminthosporium solani wywołujący parcha srebrzystego. Znaczenie choroby i jej sprawcy wynika także i z innych czynników, spośród których istotny jest brak odmian odpornych, złożony przebieg choroby z mniej znaczącą fazą polową i trudnym do opanowania etapem rozwoju podczas przechowywania. Dodatkowym czynnikiem jest także brak dostępnych środków do chemicznego zwalczania patogena. Stwierdzona w latach 70. i 80. XX w. odporność na tiabendazol stosowany zarówno wiosną jak i jesienią była jedną z ważniejszych przyczyn wzrostu znaczenia choroby. Z tych powodów zwalczanie parcha srebrzystego jest trudne i wymaga zastosowania wszystkich dostępnych metod w ochronie integrowanej.
\end{abstract}

Slowa kluczowe: choroba skórki, grzyb, Helminthosporium solani, ziemniak, zwalczanie

The long-standing market and customer demand for processed potato products and the demand for washed and packaged potatoes mean that tubers' quality (smooth skin, no signs of disease) and suitability for processing are of great importance. This tendency makes any pathogen causing skin damage of economic importance. One of them is the fungus Helminthosporium solani, the preparator of silver scab. The importance of the disease and its cause is also due to other factors: the lack of resistant varieties, the complex cycle of disease development with a less significant field phase, and a difficult-to-control phase of development during storage. An additional factor is the lack of available chemical disease control agents. The resistance to thiabendazole used both in spring and autumn, found in the 1970s and 1980s, was one of the most important reasons for the increased importance of the disease. Due to the complex cycle of disease development (field and storage phase), combating this disease is difficult and requires all available methods of integrated protection.

Keywords: disease control, fungus, Helminthosporium solani, potato, skin disease

\section{Wstęp}

Utrzymująca się na świecie tendencja do spożywania ziemniaków przetworzonych oraz mytych i paczkowanych w małe opakowania sprawia, że standardy zdrowotne bulw wymagane przez przetwórców oraz w obrocie ziemniakami świeżymi stały się wyższe. Obraz taki można obserwować także w Polsce, gdzie w ciągu ostatniego dwudziestolecia wyraźnie spadło spożycie bulw nieprzetworzonych, a wzrosło przetworów ziemniaczanych (rys. 1). Ponadto zwiększający się popyt na ziemniaki umyte i pakowane w przezroczyste worki oraz lepszą jakość produktu, na którą nalegają konsumenci sprawiają, że choroby skórki nabierają znaczenia ekonomicznego.

Jedną z tych chorób jest parch srebrzysty powodowany przez grzyba Helminthosporium solani Dur. e Mont. (synonim Helminthosporium atrovirens (Harz) E.W. Mason \& Hughes, Spondylocladium atrovirens (Harz) Harz ex Sacc.) należącego do rzędu Pleosporales, rodziny Massarinaceae (Weber 2011a). Pierwsze doniesienia o chorobie pochodzą z 1871 roku z Moskwy (Harz, 1871). Na początku XX wieku parch srebrzysty uważany był za chorobę bulw ziemniaka o małym znaczeniu, obecnie występuje ona we wszystkich rejonach jego uprawy (Errampali i in. 2001, Tian $\mathrm{i}$ in. 2007). Od lat 70. i 80. ubiegłego stulecia zaczęto notować nasilanie się porażania bulw ziemniaka przez H. solani (Adams, Hide 1980, Hide i in. 1988, Read i in. 1995), a chorobę zaczęto uważać za coraz poważniejszą (Errampali i in. 2001). Jedną z ważnych przyczyn tego wzrostu jest pojawienie się odporności grzyba $H$. solani na stosowany do jego ograniczania tiabendazol (Merida i Loria 1990; Śnieg 1992, Holley i Kawchuk 1996). 


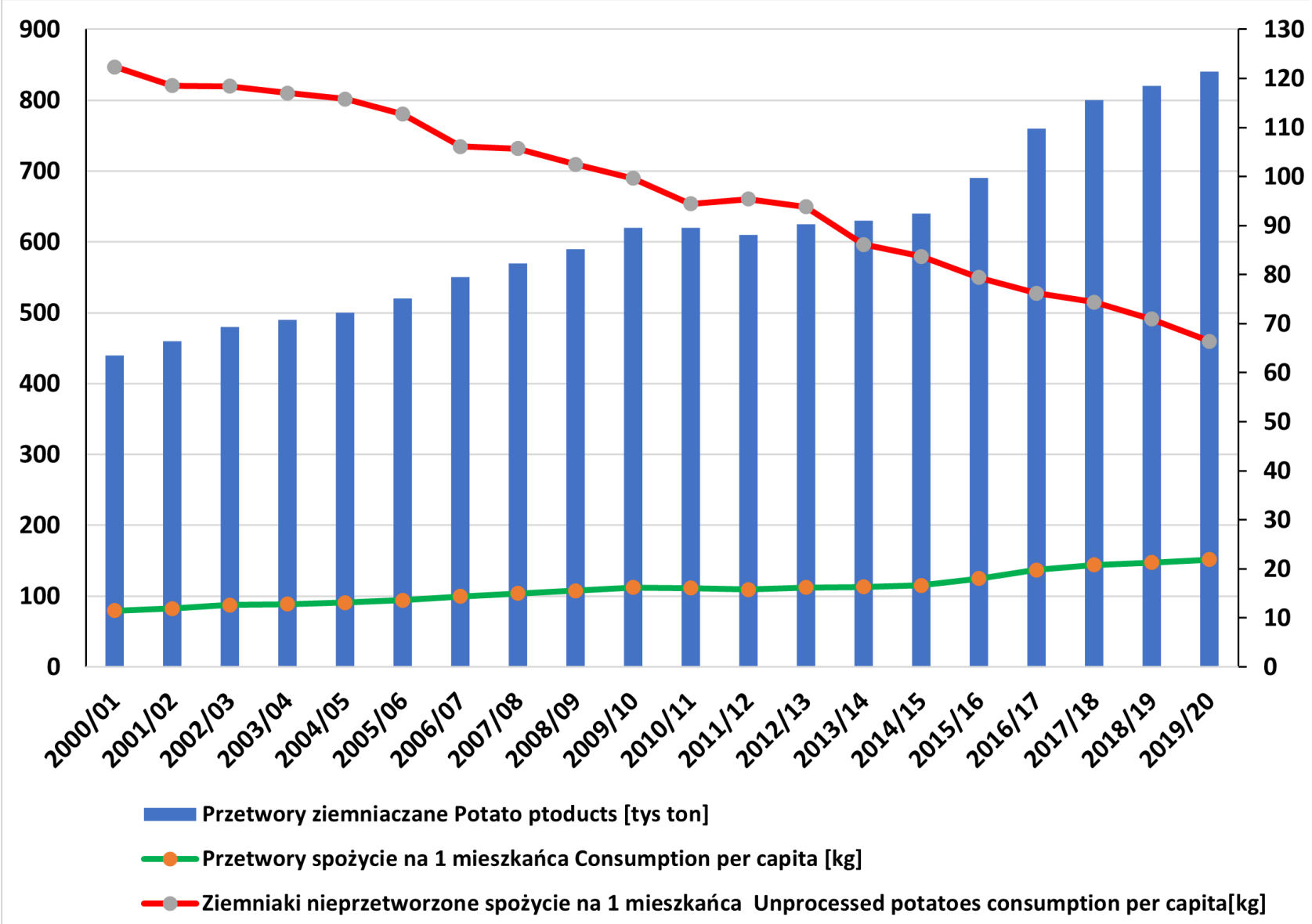

Rys. 1. Produkcja przetworów ziemniaczanych (tys. ton) i spożycie ziemniaków (kg) w przeliczeniu na mieszkańca w latach 2000-2019 w Polsce (wg Dzwonkowski i in. 2019)

Fig. 1. Production of processed potatoes (thousand tonnes) and consumption of potatoes (kg) per capita in 2000-2019 in Poland ( Dzwonkowski i in. 2019)

Innych powodów zwiększania się znaczenia parcha srebrzystego można także szukać w zmianie upodobań konsumentów i branży przetwórczej. Rosnący popyt na ziemniaki myte i pakowane w przezroczyste opakowania (Frazier i in. 1998, Errampali i in. 2001, Osowski, Bernat 2005, Wale i in. 2008) oraz wzrost spożycia produktów przetworzonych z ziemniaka (Avis i in. 2010) sprawiają, że jakość bulw (gładka skórka, brak oznak chorób) oprócz ich walorów do przetwórstwa, staje się ważna. Zwiększone zapotrzebowanie na bulwy przydatne do tych kierunków użytkowania spowodowało, że każdy patogen przyczyniający się do uszkodzenia skórki bulw, w tym sprawca parcha srebrzystego, nabrał znaczenia ekonomicznego. Ważnym więc czynnikiem decydującym o znaczeniu gospodarczym parcha srebrzystego stały się także straty ponoszone przez przemysł przetwórczy do $8,5 \mathrm{mln} \$$ w Idaho USA (Shetty i in. 1996, Brad i in. 2001) oraz handel (13\% plonu bulw handlowych na skutek odparowywania wody z uszkodzonych parchem ziemniaków) (Cunnington $\mathrm{i}$ in. 2002). Dodatkowym efektem ubocznym wpływającym na wzrost strat wynikających $z$ występowania parcha srebrzystego na skórce bulw jest gorsza jakość wysmażania się frytek i chipsów. Skórka porażona parchem nie schodzi w procesie mechanicznego obierania i w trakcie smażenia przypala się obniżając jakość i smak frytek (Holley, Kawchuk 1996).

\section{Objawy choroby}

Parch srebrzysty jest chorobą powodującą uszkodzenia skórki bulw (Avis i in. 2010, Rębarz 2018, Osowski 2019). Do infekcji grzybem dochodzi w glebie, gdzie odpadające $\mathrm{z}$ trzonków zarodniki uwalniane z zainfekowanych bulw sadzeniaka przedostają się na młode bulwy potomne. 


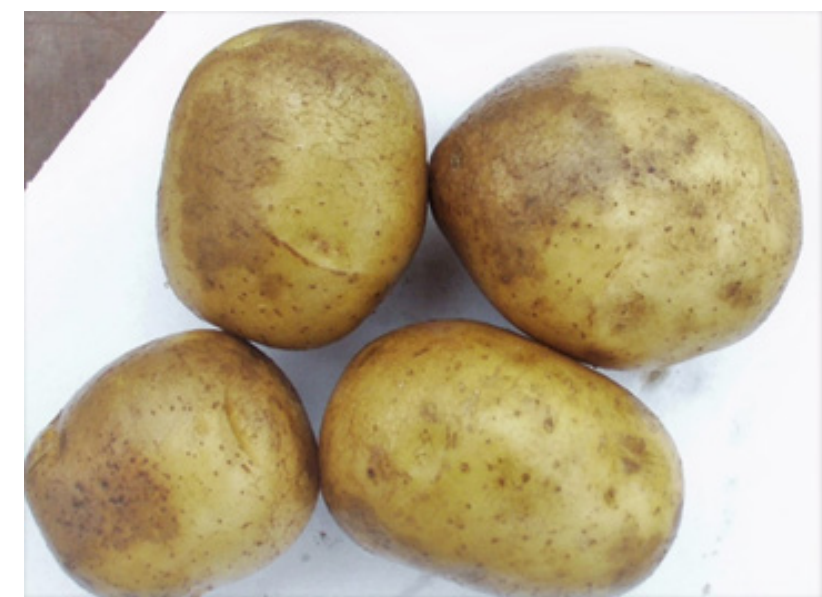

Fot. 1 Początkowe objawy choroby na bulwie

Fot. 1 Initial symptoms of the disease on the tuber

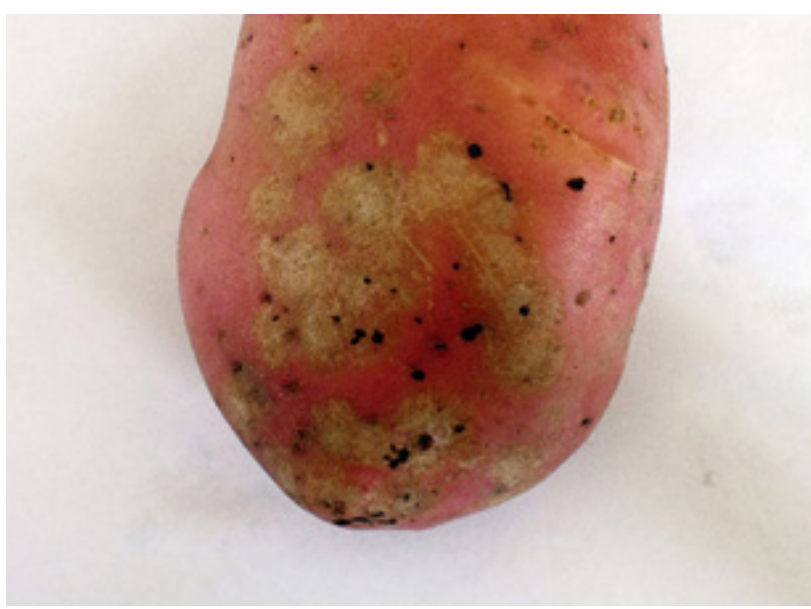

Fot. 2b Charakterystyczne objawy utraty pigmentu na skutek rozwoju choroby

Fot. 2b Characteristic symptoms of pigment loss as a result of the development of the disease

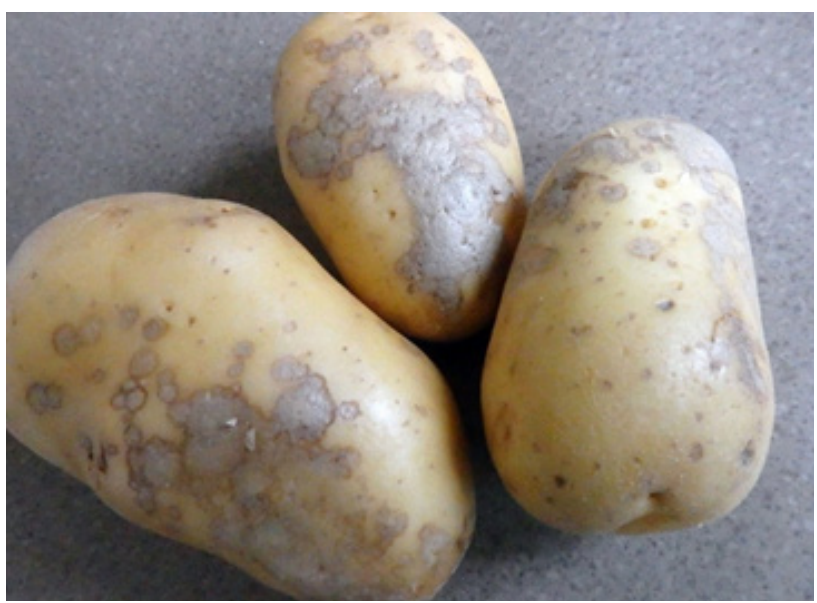

Fot. 4a Charakterystyczny wygląd nekrozy (często spotykany na bulwach $w$ sieciach handlowych)

Fot. 4a Characteristic necrosis appearance (often found on tubers in retail chains)

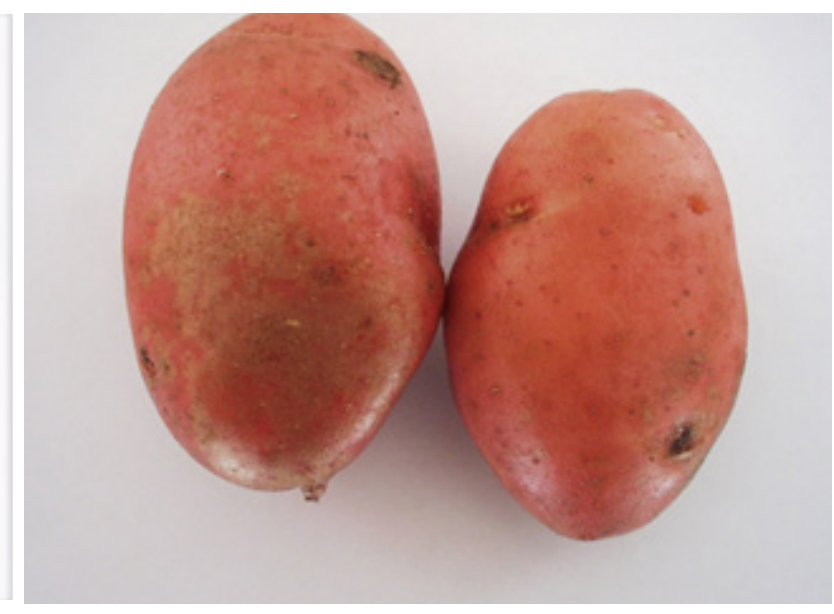

Fot. 2a Początkowe objawy choroby na bulwie o czerwonej skórce

Fot. 2a. Initial disease symptoms on red-skinned tuber

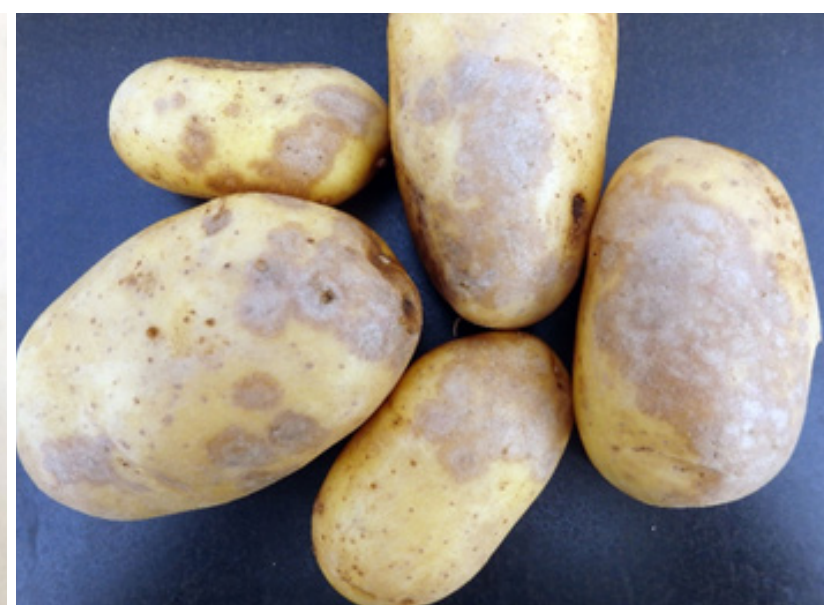

Fot. 3 Srebrzyste zabarwienie plam nekrotycznych

Fot. 3 Silvery color of necrotic spots

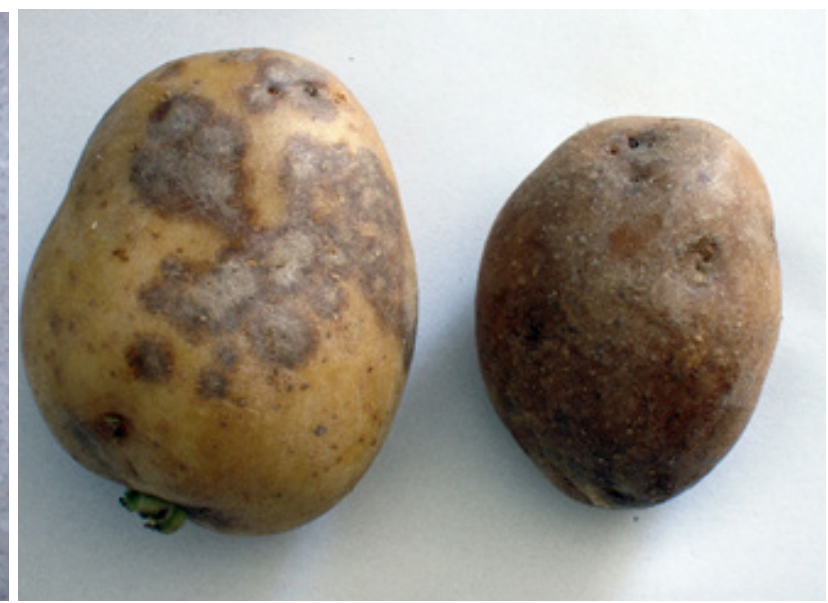

Fot. 4b Charakterystyczne ciemniejsze zabarwienie brzegów plam nekrotycznych

Fot. 4b Characteristic darker color of the edges of necrotic spots 

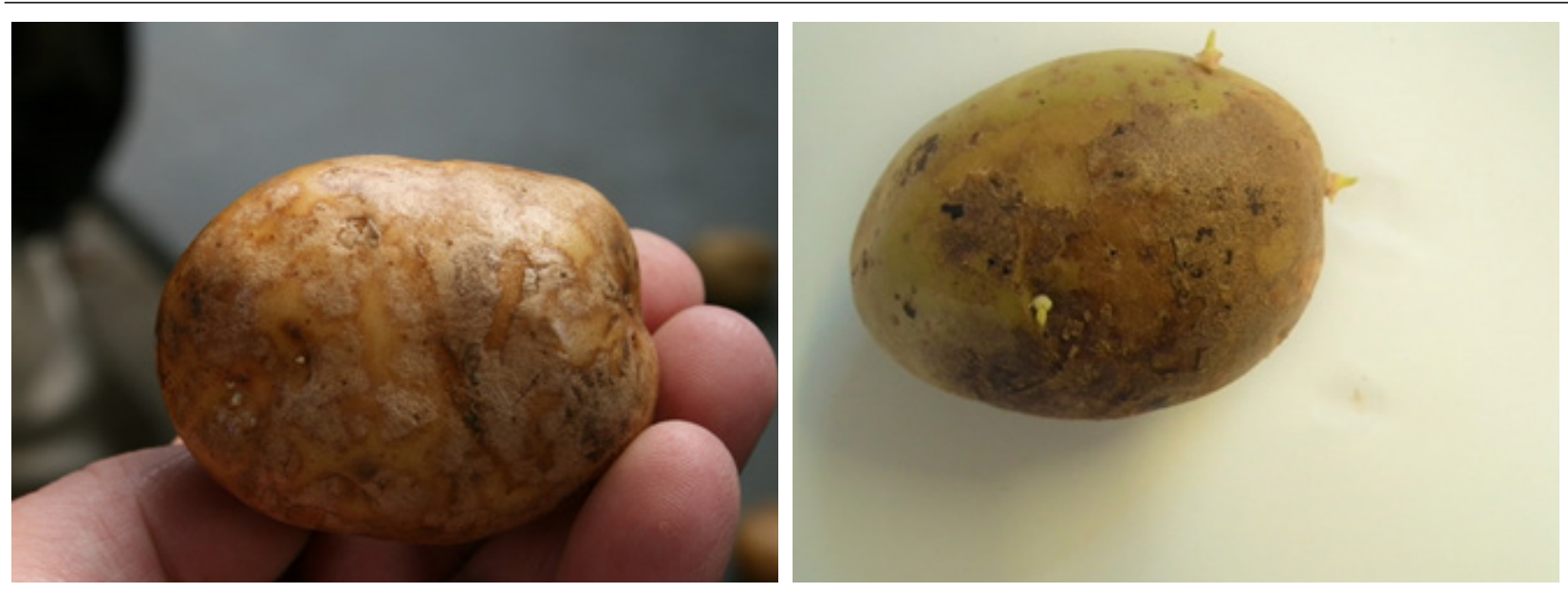

Fot. 5a i 5 b Luszczenie się naskórka z nekroz o silnym porażeniu

Fot. 5a i 5b Peeling of the epidermis from severely infested necrosis

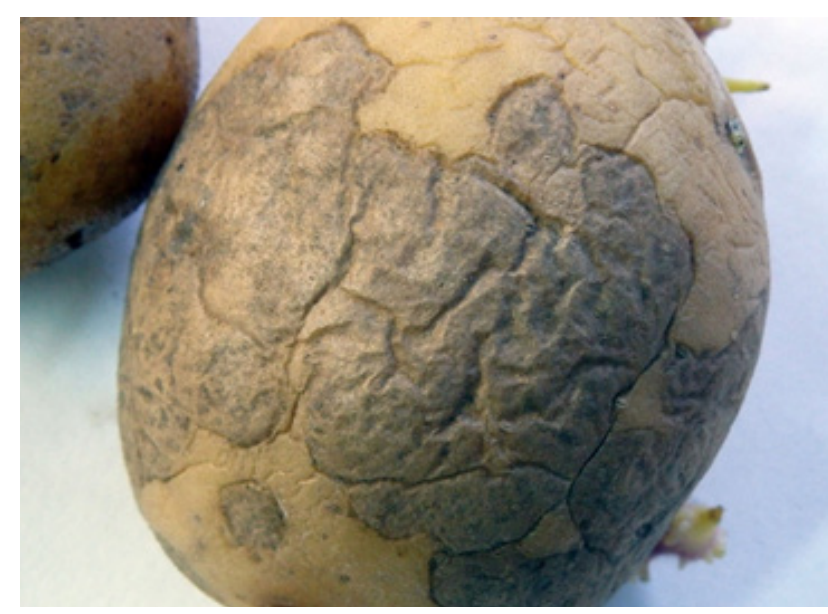

Fot. 6 Charakterystyczne pomarszczenie skórki w miejscu nekrozy (elephant ear texture)

Fot. 6 Characteristic wrinkling of the skin at the necrosis site (elephant ear texture)
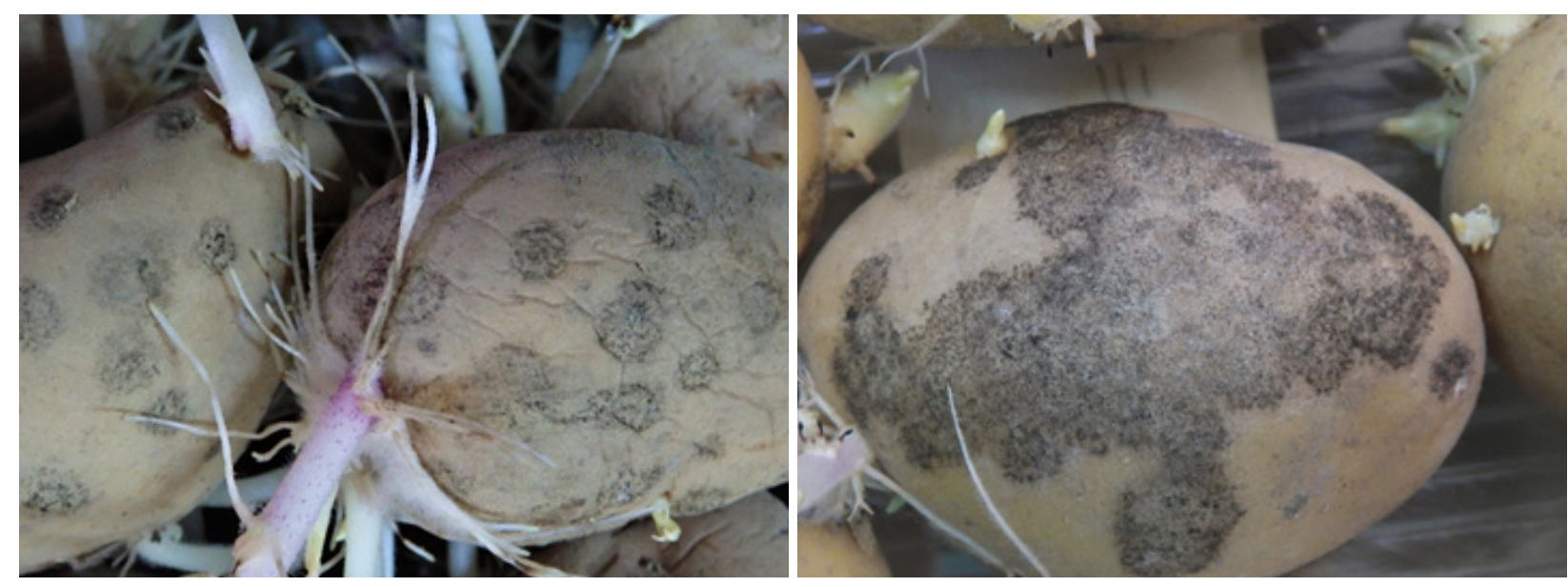

Fot. 7a i 7b Nalot utworzony ze skupisk trzonków i zarodników konidialnych (powstaje w warunkach wysokiej wilgotności)

Fot. 7a i 7b The coating formed by clusters of stems and conidial spores (occurs in high humidity conditions) 
W trakcie przechowywania symptomy zakażenia można zauważyć najczęściej $\mathrm{w}$ miejscu przyczepu bulwy do stolonu. Początkowo są to pojedyncze, jasnobrunatne, nieregularnego kształtu plamy (rys. 2), które zwiększając swoją powierzchnię mogą się łączyć ze sobą obejmując znaczną część bulwy (Secor i Gudmestad 1999, Stevenson i in. 2001, Wale i in. 2008, Osowski 2019). Na bulwach o czerwonej skórce rozwój choroby objawia się utratą pigmentu (Errampali i in. 2001), co prowadzi do powstawania charakterystycznych plam (rys. 3a i 3b). W miarę nasilania się choroby jasnobrunatne plamy na skórce stają się srebrzyste (rys. 4). Ten srebrzysty kolor tworzy się na skutek rozwarstwienia komórek i wypełnienia powietrzem powstałych szczelin (Weber 2011a). Właśnie temu charakterystycznemu zabarwieniu plam nekrotycznych choroba zawdzięcza swoją nazwę. Według Johnson i in. (2014) we wczesnych stadiach rozwoju brzegi plam ze srebrzystym wyglądem są często ciemniejsze co świadczy o tym, że może zachodzić tam proces zarodnikowania. Objawy takie często można zauważyć na bulwach umytych, które są sprzedawane w sieciach handlowych (rys. 5a, 5b). Przy silnym porażeniu można obserwować łuszczenie się skórki bulw z plam nekrotycznych (rys. 6a, 6b). Zjawisko powstaje na skutek znacznego odparowania wody, co sprawia, że skórka kurczy się i obsycha (Olivier i in. 1998). W trakcie przechowywania na porażonych ziemniakach widoczne jest silne pomarszczenie skórki bulw (rys. 7) określane jako „elephant ear texture skin” (skóra na uchu słonia) (Wale i in. 2008). W warunkach wysokiej wilgotności można zauważyć inną zmianę typową dla

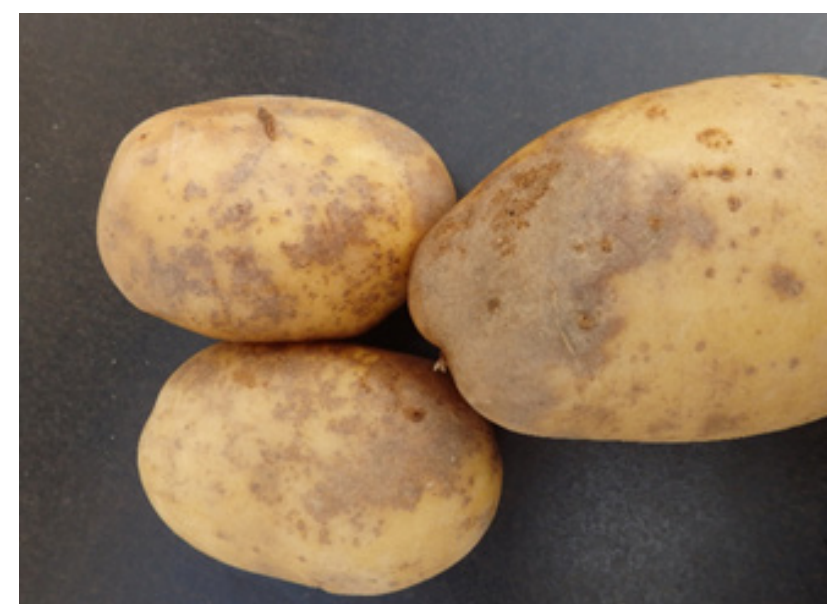

Fot. 8 Objawy antraknozy ziemniaka na bulwie

Fot. 8 Symptoms of potato anthracnose on potato tuber parcha srebrzystego. Na powierzchni plam nekrotycznych tworzy się brunatnoczarny, aksamitny nalot, który powstaje ze skupisk trzonków i zarodników konidialnych (Weber 2011a, Osowski 2019) - rys. 8 a i 8 b.

Parch srebrzysty pomimo charakterystycznych oznak jest często mylony z inną chorobą skórki bulw - antraknozą ziemniaka wywoływaną przez grzyba Colletotrichum coccodes. Na porażonych bulwach pierwsze zmiany pojawiają się jako brązowe do szarych przebarwienia o nieregularnym kształcie, które mogą obejmować znaczną część bulwy (Johnson i in. 2014, Poradnik sygnalizatora ochrony ziemniaka 2016, Rębarz 2018) - rys. 9. Jednak w odróżnieniu od objawów parcha srebrzystego brzegi nekroz spowodowanych przez $C$. coccodes są słabo oddzielone od zdrowej skórki (rys.10). Innym wspólnym symptomem, utrudniającym identyfikację, jest występowanie na powierzchni skórki nalotu. W przypadku parcha srebrzystego jest on utworzony przez skupienia trzonków i zarodników konidialnych, barwy brunatnoczarnej (Weber 2011a) - rys. 8a i 8b, a przy antraknozie ziemniaka przez mikrosklerocja (Weber 2011b) rys.11 i 12.

Według Errampali i in. (2001), sprawcę choroby można skutecznie rozpoznać po morfologii zarodników używając lupy o powiększeniu 10 x lub mikroskopu. Pod mikroskopem w przypadku H. solani widoczne są trzonki konidialne $\mathrm{z}$ wielopiętrowo ułożonymi zarodnikami. Konidia są buławkowate, ciemno zabarwione, podzielone na 5-9 gruboobłonionych komórek o wymiarach 29-66 x 6-12 $\mu \mathrm{m}$ (Wnękowski, Błaszczak 1997).

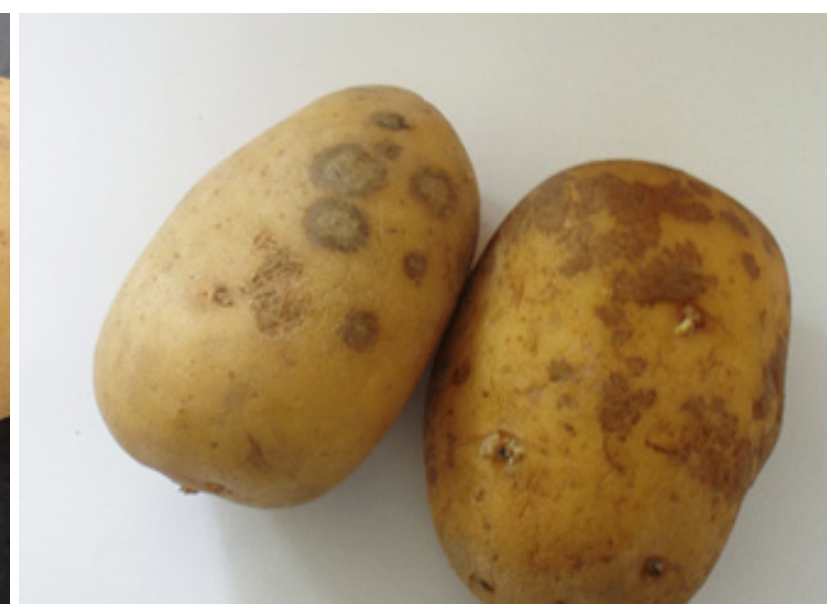

Fot. 9 Objawy parcha srebrzystego (bulwa z lewej) i antraknozy (bulwa z prawej)

Fot. 9 Symptoms of potato silver scab (tuber on the left) and anthracnose (tuber on the right) 


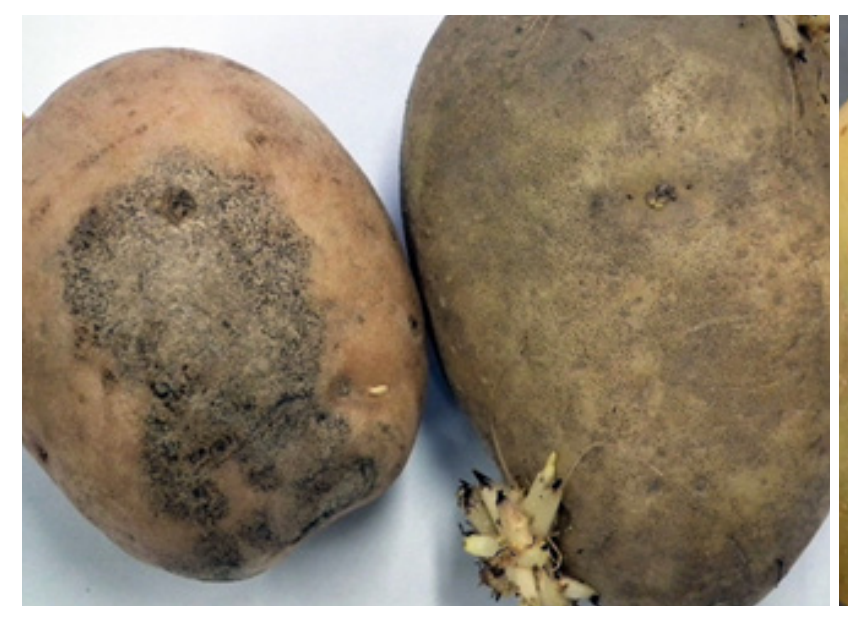

Fot. 10 Objawy zarodnikowania H. solani (bulwa $z$ lewej) i C. coccodes (bulwa z prawej)

Fot. 10 Symptoms of sporulation H. solani (tuber on the left) and $\mathrm{C}$. coccodes (tuber on the right)

\section{Cykl rozwoju}

Do infekcji bulw dochodzi w glebie, a głównym źródłem zakażenia są porażone sadzeniaki (Geary, Johnson 2006, Avis i in. 2010). Jednak Merida i Loria (1994) zwracają uwagę na znaczenie inokulum glebowego w porażeniu bulw i rozwoju choroby. W warunkach laboratoryjnych Frazier $\mathrm{i}$ in. (1998) obserwowali, że H. solani może przeżyć w glebie przez 9 miesięcy. Errampali i in. (2001) wykazali, że w doświadczeniach polowych, gdy bulwy były wysadzane na polach, na których nie uprawiano ziemniaków przez kolejne kilka lat (do 4) po zbiorze stwierdzano bulwy zainfekowane parchem srebrzystym. Merida i Loria (1994) wykrywając $H$. solani na starzejących się tkankach liści lucerny, sorgo, żyta, owsa, kukurydzy, pszenicy, rzepaku, koniczyny czerwonej i gryki wykazali, że sprawca parcha srebrzystego może być saprotrofem.

Wilgotność jest uważana za ważny czynnik zwiększający występowanie chorób. W przypadku parcha srebrzystego opinie takie są zróżnicowane. Hide i in. (1994b), Lutomirska i Szutkowska (2005) oraz Osowski i Bernat (2005) stwierdzają, że wysoka wilgotność w okresie gromadzenia plonu sprzyja rozwojowi choroby. Z kolei Adams i in. (1987), Firman i Alen (1993) oraz Errampali (2001) nie potwierdzają tej opinii. Dodatkowo Lutomirska i Szutkowska (2005) zwracają uwagę na znaczenie składu granulometrycznego gleby jako czynnika wpływającego na patogena. Stwierdzają, że gleby cięższe o skłonności do długiego utrzymywania się wilgoci są bardziej sprzyjające wystąpieniu choroby.

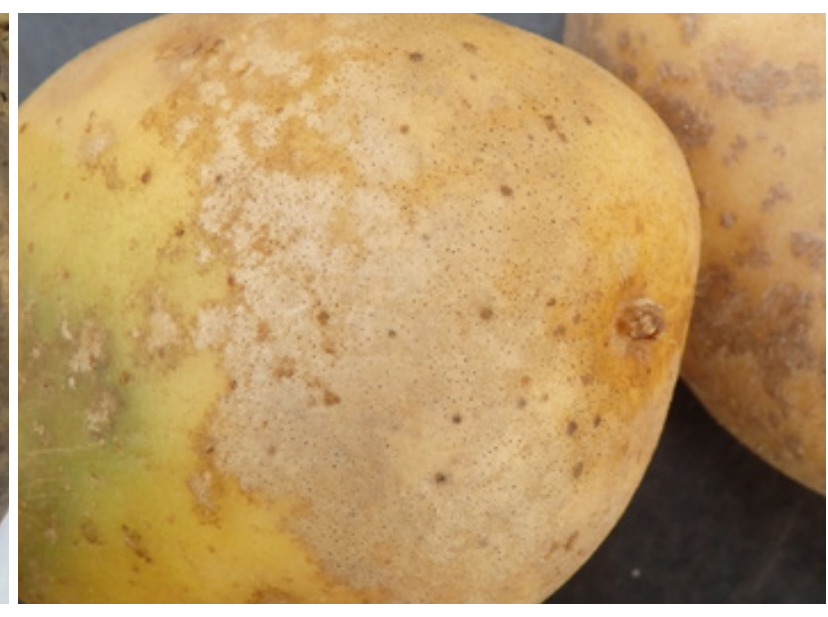

Fot. 11 Zarodnikowanie C. coccodes na bulwie

Fot. 11 Sporulation C. coccodes on the tuber

Według Errampali i in. (2001), Lutomirskiej i Szutkowskiej (2005) oraz Geary i in. (2007) w przebiegu choroby można wyróżnić dwie fazy - polową i przechowalniczą. Johnson i in. (2014) uważają, że źródłem infekcji bulw potomnych $\mathrm{w}$ polu jest inokulum pochodzące z porażonych bulw sadzeniaka, a zmiany wywołane rozwojem choroby mają nieregularny kształt i są umiejscowione na końcu rozłogu. Objawy porażenia powstające w wyniku infekcji w przechowalni pojawiają się po trzech -czterech miesiącach przechowywania (Johnson $i$ in. 2014) w dowolnym miejscu na bulwie i mają bardziej regularny kształt (rys. 5b i 10). Podczas przechowywania źródłem inokulum są zainfekowane w polu bulwy oraz zanieczyszczona gleba. Johnson i in. (2014) za możliwe źródło zarodników sprawcy uważają także skażone drewno i inne materiały organiczne. Patogen wnika do bulwy przez przetchlinki i bezpośrednio przez perydermę. Zarodniki $H$. solani znajdowano już tydzień po umieszczeniu bulw w przechowalni, gdzie konidia mogą się unosić i rozpraszać w powietrzu przez system wentylacji. Tworzą się one na powierzchni chorych bulw przy wilgotności względnej powietrza powyżej $90 \%$ i temperaturach bulwy powyżej $3^{\circ} \mathrm{C}$ (Errampali i in. 2001, Cunha, Rizzo 2004, Johnson $\mathrm{i}$ in. 2014). Zarodniki konidialne mogą stanowić źródło inokulum dla kolejnych cykli infekcji przechowywanych bulw (Rodriguez $\mathrm{i}$ in. 1996). Zakres temperatur korzystnych do rozwoju patogenu jest szeroki i waha się od $2-3^{\circ} \mathrm{Cdo} 30^{\circ} \mathrm{C}$ z optimum $21-27^{\circ} \mathrm{C}$ (Weber 2011a). Według Errampali i in. (2001) wilgotność i temperatura są istotnymi czynnikami sprzyjającymi zarodnikowaniu. 
W temperaturze $4^{\circ} \mathrm{C}$ liczba konidiów wahała się od 0 do $1,2 \times 10^{4}$, a w temperaturze $10^{\circ} \mathrm{C}$ wynosiła od 0 do 2,4 x $10^{4}$ dziennie. Rodriguez $\mathrm{i}$ in. (1996) oszacowali, że w ciągu dnia system wentylacyjny może przenieść około 24000 konidiów. Wpływ tych czynników jest także widoczny w zakażaniu ziemniaków mytych i pakowanych. Errampali i in. (2001) obserwowali wzrost infekcji bulw w ciągu 2 tygodni od ich przygotowywania i konfekcjonowania. Okres przechowywania sprzyja rozwojowi choroby, Cunha i Rizzo (2004) oceniają, że w trakcie sześciu miesięcy przechowywania powierzchnia porażenia bulw parchem srebrzystym może wzrosnąć z 3,5 do ponad 35\%. Według ich oceny w trakcie przechowywania wzrasta także liczba uszkodzonych ziemniaków powodowanych przez patogena. Intensywność choroby jest również wyższa w pierwszych miesiącach przechowywania.

\section{Sposoby ograniczania rozwoju choroby Zabiegi agrotechniczne i odporność odmian}

Errampali i in. (2001) stwierdzają, że w ograniczaniu chorób, w tym także parcha srebrzystego duże znaczenie mają zabiegi agrotechniczne takie, jak: płodozmian, data sadzenia, gęstość sadzenia, wielkość sadzeniaków i ich zdrowotność, desykacja, zbiór i jego przygotowanie do przechowywania. Johnson i in. (2014) uważają, że ziemniaki powinny być wysadzane na to samo pole po około 2 , a najlepiej po 4 latach przerwy. Wynika to z krótkiego okresu przeżywalności sprawcy choroby w glebie, którą Merida i Loria (1994) określili na 1 rok. Znaczenie płodozmianu jako czynnika zmniejszającego nasilenie choroby i ograniczającego jej negatywne skutki podkreślają także Carter i in. (2003) oraz Peters i in. (2003).
Innymi czynnikami, które mogą hamować rozwój parcha srebrzystego są termin i gęstość sadzenia. Firman i Allen (1995a) stwierdzają, że opóźnienie terminu sadzenia sprzyjało rozwojowi $H$. solani na bulwach. Według nich także duże znaczenie dla występowania choroby ma gęstość sadzenia. Dla produkcji nasiennej istotne jest gęste sadzenie (poniżej $30 \mathrm{~cm}$ ) w celu otrzymania jak największej ilości bulw frakcji sadzeniaka. Bliska odległość stwarza korzystne warunki do infekowania bulw potomnych. W swoich doświadczeniach Firman i Allen (1995a) obserwowali, że większe nasilenie choroby występowało przy gęstości sadzenia poniżej $30 \mathrm{~cm}$, a malało przy 40 centymetrach. Jako czynnik sprzyjający Adams i in. (1970) wskazują długość stolonów, na których zawiązują i rozwijają się bulwy potomne. Wyrażają pogląd, że infekcji sprzyjają krótkie stolony.

Duże znaczenie Errampali i in. (2001), Geary i in. (2007) oraz Johnson i in. (2014) przywiązują do zdrowotności sadzeniaków i wskazują je jako źródło przenoszenia choroby na sezon następny uważając, że poziom porażenia sadzeniaków ma wpływ na nasilenie choroby. Firman i Allen (1995b) stwierdzają, że do zaistnienia choroby wystarczy niewielkie, 5\% porażenie skórki bulw. Errampali i in. (2001) za jedną z przyczyn wzrostu znaczenia choroby uważają brak wysokiego poziomu odporności uprawianych odmian na parcha srebrzystego. W programach hodowlanych próbowano zwiększyć odporność odmian ziemniaka wykorzystując do tego celu dzikie gatunki Solanum spp., jednak nie uzyskano całkowitej odporności (Murphy i in. 1999, Avis i in. 2010). Także badania prowadzone przez IHAR-PIB, Oddział w Jadwisinie wykazały zróżnicowanie odporności

Odporność odmian ziemniaka na parcha srebrzystego (wg Charakterystyka Odmian 2020)

The resistance of potato cultivarss to silver scab (according to Cultivar Characteristic 2020)

\begin{tabular}{|c|c|c|}
\hline Odmiana Cultivar & $\begin{array}{l}\text { Typ kulinarny** } \\
\text { Culinary type }\end{array}$ & $\begin{array}{l}\text { Parch srebrzysty* } \\
\text { Silver scab }\end{array}$ \\
\hline \multicolumn{3}{|c|}{$\begin{array}{l}\text { Odmiany jadalne bardzo wczesne } \\
\text { Very early table cultivars }\end{array}$} \\
\hline Berber & B & 5,5 \\
\hline Denar & $\mathrm{AB}$ & 6 \\
\hline Fresco & B & 4 \\
\hline Impala & $\mathrm{AB}$ & 5,5 \\
\hline Irys & B & 6 \\
\hline Justa & $\mathrm{B} / \mathrm{BC}$ & 6 \\
\hline Lord & $\mathrm{AB}$ & 5 \\
\hline
\end{tabular}

\begin{tabular}{|c|c|c|}
\hline Odmiana Cultivar & $\begin{array}{l}\text { Typ kulinarny** } \\
\text { Culinary type }\end{array}$ & $\begin{array}{l}\text { Parch srebrzysty* } \\
\text { Silver scab }\end{array}$ \\
\hline \multicolumn{3}{|c|}{$\begin{array}{c}\text { Odmiany jadalne średnio wczesne } \\
\text { Mid early table cultivars }\end{array}$} \\
\hline Jurek & $\mathrm{B}-\mathrm{BC}$ & 6 \\
\hline Laskara & $\mathrm{B}-\mathrm{BC}$ & 6,1 \\
\hline Lech & $\mathrm{B}-\mathrm{BC}$ & 5,2 \\
\hline Malaga & $\mathrm{B}-\mathrm{BC}$ & 6,4 \\
\hline Mazur & $\mathrm{BC}$ & 5,2 \\
\hline Oberon & $\mathrm{AB}$ & 4,9 \\
\hline Orchestra & $\mathrm{AB}$ & 7 \\
\hline
\end{tabular}


Tabela 1 cd.

Table 1 cont.

Odporność odmian ziemniaka na parcha srebrzystego (wg Charakterystyka Odmian 2020)

The resistance of potato cultivarss to silver scab (according to Cultivar Characteristic 2020)

\begin{tabular}{|c|c|c|}
\hline Miłek & $\mathrm{BC}$ & 6 \\
\hline Riviera & $\mathrm{A}-\mathrm{AB}$ & 6,1 \\
\hline Tacja & $\mathrm{B}$ & 4,9 \\
\hline Tonacja & $\mathrm{AB}$ & 5,7 \\
\hline Viviana & $\mathrm{AB}$ & 7 \\
\hline \multicolumn{3}{|c|}{$\begin{array}{l}\text { Odmiany jadalne wczesne } \\
\text { Early table cultivars }\end{array}$} \\
\hline Altesse & $\mathrm{AB}$ & 5,8 \\
\hline Bellarosa & B & 6 \\
\hline Bila & $\mathrm{B}$ & 5 \\
\hline Bohun & $\mathrm{B}$ & 6,2 \\
\hline Carrera & B & 6,5 \\
\hline Gwiazda & $\mathrm{B}$ & 6 \\
\hline Ignacy & $\mathrm{B}$ & 6,5 \\
\hline Innovator & $\mathrm{B} / \mathrm{BC}$ & 4 \\
\hline Latona & B & 4 \\
\hline Lawenda & B & 5,4 \\
\hline Madaleine & B & 6,8 \\
\hline Michalina & B & 5,5 \\
\hline Owacja & $\mathrm{B} / \mathrm{BC}$ & 5,5 \\
\hline Vineta & $\mathrm{B} / \mathrm{AB}$ & 4,5 \\
\hline \multicolumn{3}{|c|}{$\begin{array}{l}\text { Odmiany jadalne średnio wczesne } \\
\text { Mid early table cultivars }\end{array}$} \\
\hline Asterix & $\mathrm{B}$ & 3,5 \\
\hline Bojar & B-BC & 6,3 \\
\hline Cekin & $\mathrm{BC} / \mathrm{C}$ & 4,5 \\
\hline Dali & AB-B & 4,5 \\
\hline Ditta & $\mathrm{B}$ & 4 \\
\hline Finezja & $\mathrm{BC}$ & 7 \\
\hline Folva & $\mathrm{B}$ & 6 \\
\hline Honorata & $\mathrm{BC}$ & 6,5 \\
\hline Irga & $\mathrm{B}$ & 5 \\
\hline Jurata & & 6,5 \\
\hline
\end{tabular}

\begin{tabular}{ccc}
\hline Sagitta & B & 6 \\
\hline Sante & B & 5 \\
\hline Satina & B & 4,5 \\
\hline Tajfun & BC/B & 5,5 \\
\hline Victoria & B & 6 \\
\hline \multicolumn{3}{c}{$\begin{array}{c}\text { Odmiany skrobiowe wczesne } \\
\text { Starchy early cultivars }\end{array}$} \\
\hline Cedron & 4 \\
\hline
\end{tabular}

Odmiany skrobiowe średnio wczesne Starchy mid early cultivars

\begin{tabular}{cc}
\hline Boryna & 4,5 \\
\hline Glada & 4 \\
\hline Harpun & 5 \\
\hline Jubilat & 5 \\
\hline Kaszub & 4 \\
\hline Kuba & 3,5 \\
\hline Mieszko & 5,7 \\
\hline Pasat & 5 \\
\hline Rumpel & 3,5 \\
\hline Szyper & 6 \\
\hline Zuzanna & 6 \\
\hline
\end{tabular}

Odmiany skrobiowe średnio późne Starchy mid late vcultivars

\begin{tabular}{cc}
\hline Amarant & 4,7 \\
\hline Ikar & 4 \\
\hline Pasja Pomorska & 4 \\
\hline \multicolumn{2}{c}{$\begin{array}{l}\text { Odmiany skrobiowe późne } \\
\text { Starch late cultivars }\end{array}$} \\
\hline Bzura & 4 \\
\hline Hinga & 5 \\
\hline Inwestor & 5,5 \\
\hline Jasia & 3,5 \\
\hline Kuras & 5,5 \\
\hline Pokusa & 5 \\
\hline Rudawa & 4 \\
\hline Skawa & 3,5 \\
\hline
\end{tabular}

*skala 9-stopniowa, gdzie 9 oznacza catkowita odporność, a 1 największa podatność;

The 9-point scale where the score of 9 indicates the maximum level of resistance and the score of 1 - the highest susceptibility

** A-salatkowy $A$-salad/waxy, $A B$ - salatkowy do wszechstronnie uzytkowego, $A B$ - waxy to the all-rounder

$B$ - wszechstronnie użtkowy B-all-purpose, $C$ - maczysty $C$ - mealy/starchy 
odmian ziemniaka zarejestrowanych w Krajowym Rejestrze Odmian (tab. 1).

Jak uważają Merida i Loria (1994) wpływ na nasilenie choroby ma nie tylko termin sadzenia, ale także termin zbioru. Według nich długość ekspozycji bulw potomnych na sprawcę (termin od zawiązywania bulw do zbioru) jest ważnym czynnikiem wpływającym na rozwój choroby. Opóźnianie terminu zbioru bulw sprzyja ich porażeniu przez grzyba. Również Firman i Allen (1995b) potwierdzają, że wcześniejszy termin zbioru zmniejsza poziom choroby. W swoich doświadczeniach uzyskali niższe porażenie parchem srebrzystym po przechowaniu bulw zbieranych we wcześniejszych terminach. Merida i Loria (1994) uważają, że głównym wyznacznikiem nasilenia choroby jest czas pomiędzy zawiązywaniem bulw a terminem zbioru. Wczesne zamieranie roślin sprzyja porażeniu bulw potomnych, ponieważ skórka bulw zaczyna szybciej dojrzewać (Johnson i in. 2014). Dlatego należy jak najdłużej utrzymywać rośliny w stanie zielonym.

\section{Przygotowanie do przechowywania i przechowy- wanie}

Cykl rozwoju choroby ma dwie fazy: polową i przechowalniczą (Errampali i in. 2001). Infekcja pierwotna występuje zarówno w polu, jak i podczas przechowywania, a konidia produkowane $\mathrm{w}$ przechowalniach służą jako inokulum do wtórnych cykli infekcji. Znaczenie właściwego przygotowania bulw do przechowywania jako istotnego czynnika ograniczającego możliwość rozwoju choroby jest podkreślane w wielu pracach (Errampali $\mathrm{i}$ in. 2001, Cunha i Rizzo 2004, Avis i in. 2010, Johnson i in. 2014). Zapewnienie odpowiednich warunków sanitarnych oraz usuwanie resztek roślin i gleby zmniejsza nasilenie choroby przez cały okres przechowywania, gdyż redukuje ilość inokulum w pobliżu bulw.

Istotnym czynnikiem jest także redukcja wilgotności względnej powietrza w przechowalni i unikanie kondensacji wilgoci na bulwach, która stwarza korzystne warunki do zarodnikowania sprawcy (Avis i in. (2010). Konidia grzyba roznoszą się poprzez systemy wentylacji i zakażają inne bulwy (Hardy i in. 1997). Doświadczenia Fraziera i in. (1998) wykazały, że zmniejszenie poziomu wilgotności względnej z $95 \%$ do $85 \%$ obniża nasilenie parcha srebrzystego. Secor i Gudmestad (1999) wyrażają pogląd, że redukcja poziomu wilgotności względnej powietrza do 90\% w pierwszym miesiącu przechowywania opóźnia sporulację patogenu. Errampali i in. (2001) oraz

Tabela 2

Table 2

Warunki wymagane podczas przechowywania ziemniaków (Czerko 2016)

Conditions required for the storage of potatoes (Czerko 2016)

\begin{tabular}{|c|c|c|c|c|}
\hline $\begin{array}{l}\text { Etap przechowywania } \\
\text { Storage stage }\end{array}$ & $\begin{array}{l}\text { Czas trwania } \\
\text { Duration }\end{array}$ & $\begin{array}{l}\text { Rodzaj użytkowania } \\
\text { Type of use }\end{array}$ & $\begin{array}{l}\text { Temperatura }\left({ }^{\circ} \mathrm{C}\right) \\
\text { Temperature }\left({ }^{\circ} \mathrm{C}\right)\end{array}$ & $\begin{array}{c}\text { Wilgotność powietrza (\%) } \\
\text { Air humidity }(\%)\end{array}$ \\
\hline I osuszanie/drying & 3-5 dni/days & $\begin{array}{l}\text { wszystkie kierunki/ } \\
\text { all directions }\end{array}$ & $12-18$ & $75-90$ \\
\hline II dojrzewanie/ripening & 10-14 dni/days & $\begin{array}{l}\text { wszystkie kierunki/ } \\
\text { all directions }\end{array}$ & $12-18$ & $90-95$ \\
\hline III schładzanie/cooling & $\begin{array}{l}\text { 3-6 tygodni/ } \\
\text { weeks }\end{array}$ & $\begin{array}{l}\text { wszystkie kierunki/ } \\
\text { all directions }\end{array}$ & $\begin{array}{c}\text { obniżanie o } 0,2-0,5^{\circ} \mathrm{C} \\
\text { na dzień }\end{array}$ & $90-95$ \\
\hline \multirow{4}{*}{ IV przechowywanie/storage } & $\begin{array}{l}6-7 \text { m-cy/ } \\
\text { months }\end{array}$ & sadzeniaki/seed & $2-6$ & \multirow{4}{*}{$90-95$} \\
\hline & $\begin{array}{l}\text { do } 8 \mathrm{~m}-\mathrm{cy} / \\
\text { months }\end{array}$ & jadalne/table & $4-6$ & \\
\hline & $\begin{array}{c}\text { do } 9 \text { m-cy/ } \\
\text { months }\end{array}$ & $\begin{array}{l}\text { przetwórstwo spożywcze/ } \\
\text { food processing }\end{array}$ & $6-8$ & \\
\hline & $3-8 \mathrm{~m}-\mathrm{cy}$ & $\begin{array}{c}\text { pasza, przemys } 1 \text { forage, } \\
\text { processing }\end{array}$ & $2-4$ & \\
\hline \multirow{2}{*}{$\begin{array}{l}\text { V przygotowanie do użytko- } \\
\text { wania/preparation for use }\end{array}$} & \multirow{2}{*}{$\begin{array}{l}\text { około } 10 \text { dni } \\
\text { about } 10 \text { days }\end{array}$} & $\begin{array}{c}\text { jadalne, przetwórstwo/table, } \\
\text { processing }\end{array}$ & 10 & $85-95$ \\
\hline & & sadzeniaki/seed & $10-15^{*}$ & $75-80$ \\
\hline
\end{tabular}

* temperatura właściwa dla prowadzenia podkietkowania/temperature proper to induce pre-sprouting 
Avis i in. (2010) za istotny czynnik ograniczający rozwój choroby uważają właściwe przygotowanie bulw do przechowywania. Wyróżniają oni w tym okresie trzy fazy: I - zabliźnianie ran i uszkodzeń, II - schładzanie i III - przechowywanie. W warunkach Polski Czerko (2016) okres przygotowania do przechowywania oraz przechowywanie i przygotowywanie do przerobu i sadzenia dzieli na 5 etapów (tab. 2).

Bulwy zbierane w dobrych warunkach dojrzewają (przechodzą okres zabliźniania i gojenia uszkodzeń i ran oraz suberyzacji) w temperaturze od 10 do $15^{\circ} \mathrm{C}$ przez okres od dwóch do trzech tygodni (Errampali i in. 2001, Czerko 2016). Okres ten, nie tylko zapobiega wtórnym infekcjom przez patogeny powodujące choroby przechowalnicze, ale także korzystnie wpływa na ograniczenie rozwoju parcha srebrzystego. Wydłużenie tego okresu jeszcze bardziej ogranicza rozwój choroby (Hide i in. 1994b). Natomiast brak etapu dojrzewania w trakcie przygotowań do przechowywania skutkuje wzrostem infekcji $H$. solani.

Kolejnym etapem przygotowującym bulwy do długotrwałego przechowywania jest okres stopniowego ich schładzania do temperatury korzystnej dla kierunku ich wykorzystania (tab. 2). Zbyt gwałtowne wahania temperatury mogą prowadzić do kondensacji pary wodnej, co może zwiększyć podatność skórki bulw i ilość konidiów sprawcy. Liczba konidiów w zależności od temperatury może wynosić od $1 \times 10^{6} \mathrm{w}$ temperaturze $5^{\circ} \mathrm{C}$ do $1,7 \times 10^{7} \mathrm{w}$ temperaturze $15^{\circ} \mathrm{C}$ (Hardy $\mathrm{i}$ in. 1997, Pringle i in. 1998). Avis i in. (2010) uważają, że generalnie obniżanie temperatury podczas okresu przechowywania jest jednym ze skutecznych sposobów ograniczania rozwoju parcha srebrzystego. Ogilvy (1992) wykazał, że składowanie bulw w temperaturze do $4^{\circ} \mathrm{C}$ jest efektywniejszym sposobem hamowania rozwoju patogenu w porównaniu do zabiegów fungicydowych. Należy jednak pamiętać, że zmiany warunków przechowywania mogą oddziaływać na bulwy, a szczególnie na ich jakość. Nadmierne zmniejszanie wilgotności względnej w celu zwalczania parcha srebrzystego może wpływać na zwiększone odparowywanie i utratę wagi bulw. Ponadto przechowywanie bulw w temperaturze $4^{\circ} \mathrm{C}$ jest powszechnie stosowane w przypadku sadzeniaków oraz bulw przeznaczonych do sprzedaży jako świeże do bezpośredniego spożycia. Przetrzymywanie $\mathrm{w}$ tej temperaturze bulw do przerobu na frytki i chipsy nie jest wskazane, gdyż obniży to ich jakość (gorszy kolor wysmażania).

\section{Ochrona chemiczna i biologiczna}

Za przyczyny wzrostu znaczenia parcha srebrzystego Errampali i in. (2001), Cunha i Rizzo (2003) uznają nie tylko brak odmian odpornych na chorobę, ale także pojawienie się odpornych izolatów sprawcy na stosowane fungicydy. Jednym z powodów wzrostu nasilenia choroby może być odporność sprawcy na tiabendazol stosowany zarówno jesienią po zbiorze jak i wiosną przed sadzeniem (Errampali i in. 2001). Przed wprowadzeniem tiabendazolu do powszechnego stosowania parcha srebrzystego zwalczano wykorzystując środki odkażające i fungicydy do zabiegów glebowych oraz zaprawiania bulw. Potwierdzona w latach 70. i 80. ubiegłego stulecia odporność na tiabendazol spowodowała, że zaczęto poszukiwać nowych substancji skutecznie zwalczających parcha srebrzystego. Przebadano wiele substancji (tab. 3), a wyniki były bardzo zróżnicowane (Avis $\mathrm{i}$ in. 2010).

Cayley i in. (1983) oraz Jellis i Taylor (1977) stwierdzili mniejsze porażenie bulw potomnych po zastosowaniu imazalilu i benomylu. Tsror i Peretz-Alon (2004) także potwierdzają skuteczność imazalilu, a dodatkowo tak jak Ogilvy (1992) uzyskali pozytywne efekty po użyciu fludioksonilu i azoksystrobiny. Badania Kutuzowej i in. (2017) potwierdziły skuteczność difenokonazol oraz srebra koloidalnego w ograniczaniu rozwoju H. solani w przypadku azoksystrobiny uzyskane wyniki nie dały jednoznacznej odpowiedzi. Pasche i in. (2005) oraz Pobiedinskaya i in. (2012) zwrócili uwagę na potwierdzoną odporność innych patogenów roślin na działanie tej substancji aktywnej. Wyrazili także zdanie, że powszechne, doglebowe stosowanie azoksystrobiny przeciwko $H$. solani może wkrótce doprowadzić do powstania odpornych szczepów sprawcy.

Rodriguez i in. (1996) zwracają uwagę na aspekt rozwoju choroby i wzrost jej nasilenia w okresie przechowywania. Stwierdzają, że ze względu na wydłużający się czas składowania i wzrost infekcji może być konieczne stosowanie zabiegów bezpośrednio przed przechowywaniem lub w jego trakcie. Podobną opinię wyrażają Denner i in. (1997). Różnice w skuteczności badanych fungicydów wykazywane w doświadczeniach prowadzonych w różnych ośrodkach, mogą wynikać z wielu przyczyn, między innymi z: poziomu inokulum sprawcy w glebie, rodzaju gleby, populacji drobnoustrojów glebowych oraz warunków środowiskowych (Geary i in. 2007). Jako czynnik obniżający efektywność działania zastosowanych 
Skuteczność różnych substancji aktywnych w ograniczaniu parcha srebrzystego (opracowanie wg Avis i in. 2010)

Effectiveness of various active substances in reducing potato silver scab (Avis et al. 2010)

\begin{tabular}{|c|c|c|c|}
\hline $\begin{array}{l}\text { Substancja aktywna } \\
\text { fungicydu } \\
\text { Fungicide active ingre- } \\
\text { dients }\end{array}$ & $\begin{array}{l}\text { Sposób aplikacji } \\
\text { Aplication method }\end{array}$ & $\begin{array}{c}\text { Redukcja } \\
\text { choroby } \\
\text { Disease reduc- } \\
\text { tion }\end{array}$ & $\begin{array}{l}\text { Literatura } \\
\text { References }\end{array}$ \\
\hline \multirow{2}{*}{$\begin{array}{l}\text { Azoksystrobina/azoxy- } \\
\text { strobin }\end{array}$} & $\begin{array}{l}\text { zaprawianie bulw/ } \\
\text { seed dressing }\end{array}$ & $\begin{array}{l}\text { skutecznie/ } \\
\text { effectively }\end{array}$ & Geary i in. (2000), Tsror, Peretz-Alon (2004), Geary i in. (2007) \\
\hline & $\begin{array}{l}\text { zaprawianie bulw/ } \\
\text { seed dressing }\end{array}$ & brak/none & Hervieux $\mathrm{i}$ in. (2001) \\
\hline Kaptan/captan & $\begin{array}{l}\text { oprysk po zbiorze/ } \\
\text { spraying after } \\
\text { harvest }\end{array}$ & $\begin{array}{l}\text { skutecznie/ } \\
\text { effectively }\end{array}$ & Copeland, Logan (1975) \\
\hline Kaptafol/captafol & $\begin{array}{l}\text { oprysk po zbiorze/ } \\
\text { spraying after } \\
\text { harvest }\end{array}$ & $\begin{array}{l}\text { skutecznie/ } \\
\text { effectively }\end{array}$ & Copeland, Logan (1975) \\
\hline \multirow{2}{*}{ Fenpiklonil/fenpiclonil } & $\begin{array}{l}\text { zaprawianie bulw/ } \\
\text { seed dressing }\end{array}$ & $\mathrm{brak} / \mathrm{none}$ & Cooke, Little (1995) \\
\hline & $\begin{array}{l}\text { zaprawianie bulw/ } \\
\text { seed dressing }\end{array}$ & $\begin{array}{l}\text { skutecznie/ } \\
\text { effectively }\end{array}$ & Gaucher (1998), Leadbeater, Kirk (1992), Welsh (1996); \\
\hline \multirow[t]{2}{*}{ Fludioksonil/fludioxonil } & $\begin{array}{l}\text { zaprawianie bulw/ } \\
\text { seed dressing }\end{array}$ & $\begin{array}{l}\text { skutecznie/ } \\
\text { effectively }\end{array}$ & $\begin{array}{l}\text { Shetty i in. (1994, Frazier i in. (1998); Gearyi in. (2000), Errampalli i } \\
\text { in. (2001), Tsror, Peretz-Alon (2004), Geary i in. (2007) }\end{array}$ \\
\hline & $\begin{array}{l}\text { zaprawianie bulw/ } \\
\text { seed dressing }\end{array}$ & $\mathrm{brak} /$ none & Hervieux $\mathrm{i}$ in. (2001) \\
\hline Flutolanil/flutolanil & $\begin{array}{l}\text { zaprawianie bulw/ } \\
\text { seed dressing }\end{array}$ & $\begin{array}{l}\text { skutecznie/ } \\
\text { effectively }\end{array}$ & Gaucher (1998) \\
\hline Fuberidazol/fuberidazol & $\begin{array}{l}\text { oprysk po zbiorze/ } \\
\text { spraying after } \\
\text { harvest }\end{array}$ & $\begin{array}{l}\text { skutecznie/ } \\
\text { effectively }\end{array}$ & Copeland, Logan (1975) \\
\hline \multirow[t]{2}{*}{ Imazalil/imazalil } & $\begin{array}{l}\text { oprysk po zbiorze/ } \\
\text { spraying after } \\
\text { harvest }\end{array}$ & $\begin{array}{l}\text { skutecznie/ } \\
\text { effectively }\end{array}$ & $\begin{array}{l}\text { Cayley i in. (1983), Hide i in. (1987), Hall, Hide (1992), Collet-Eli- } \\
\text { mane, Jouan (1993), Hide (1994); Hide i in. (1994a), Tsror, Peretz-A- } \\
\text { lon (2002); Tsror, Peretz-Alon (2004) }\end{array}$ \\
\hline & $\begin{array}{l}\text { zaprawianie bulw/ } \\
\text { seed dressing }\end{array}$ & $\mathrm{brak} /$ none & Cooke, Little (1995), Hervieux i in. (2001) \\
\hline \multirow{2}{*}{ Iprodion/iprodion } & $\begin{array}{l}\text { zaprawianie bulw/ } \\
\text { seed dressing }\end{array}$ & $\mathrm{brak} /$ none & Hervieux $\mathrm{i}$ in. (2001) \\
\hline & $\begin{array}{l}\text { zaprawianie bulw/ } \\
\text { seed dressing }\end{array}$ & $\begin{array}{l}\text { skutecznie/ } \\
\text { effectively }\end{array}$ & Tsror, Peretz-Alon (2004) \\
\hline \multirow[t]{2}{*}{ Mankozeb/mancozeb } & $\begin{array}{l}\text { zaprawianie bulw/ } \\
\text { seed dressing }\end{array}$ & $\begin{array}{l}\text { skutecznie/ } \\
\text { effectively }\end{array}$ & $\begin{array}{c}\text { Collet-Elimane, Jouan (1993), Le Corre i in. (1993); Gaucher (1998), } \\
\text { Tsror, Peretz-Alon (2004) }\end{array}$ \\
\hline & $\begin{array}{l}\text { zaprawianie bulw/ } \\
\text { seed dressing }\end{array}$ & $\mathrm{brak} /$ none & Hervieux i in. (2001), Geary $i$ in. (2007) \\
\hline Pencykuron/pencycuron & $\begin{array}{l}\text { zaprawianie bulw/ } \\
\text { seed dressing }\end{array}$ & $\mathrm{brak} /$ none & Cooke, Little (1995) \\
\hline Prochloraz/prochloraz & $\begin{array}{l}\text { zaprawianie bulw/ } \\
\text { seed dressing }\end{array}$ & $\begin{array}{l}\text { skutecznie/ } \\
\text { effectively }\end{array}$ & Denner i in. (1997), Hide i in. (1987), Tsror, Peretz-Alon (2004) \\
\hline Propiconazol/propikonazol & $\begin{array}{l}\text { zaprawianie bulw/ } \\
\text { seed dressing }\end{array}$ & $\begin{array}{l}\text { skutecznie/ } \\
\text { effectively }\end{array}$ & Bisht, Bains (1995), Hide i in. (1987) \\
\hline Propineb/propineb & $\begin{array}{l}\text { zaprawianie bulw/ } \\
\text { seed dressing }\end{array}$ & $\begin{array}{l}\text { skutecznie/ } \\
\text { effectively }\end{array}$ & Tsror, Peretz-Alon (2004) \\
\hline \multirow{2}{*}{$\begin{array}{c}\text { Tiofanat-metylu/thiopha- } \\
\text { nate-methyl }\end{array}$} & $\begin{array}{l}\text { zaprawianie bulw/ } \\
\text { seed dressing }\end{array}$ & $\begin{array}{l}\text { skutecznie/ } \\
\text { effectively }\end{array}$ & Jouan i in. (1974), Bisht, Bains (1995) \\
\hline & $\begin{array}{l}\text { zaprawianie bulw/ } \\
\text { seed dressing }\end{array}$ & $\begin{array}{l}\text { skutecznie/ } \\
\text { effectively }\end{array}$ & Frazier i in. (1998), Geary i in. (2007) \\
\hline Tiram/thiram & $\begin{array}{l}\text { oprysk po zbiorze/ } \\
\text { spraying after } \\
\text { harvest }\end{array}$ & $\begin{array}{l}\text { skutecznie/ } \\
\text { effectively }\end{array}$ & Copeland, Logan (1975) \\
\hline Tolylfluanid/tolylfluanid & $\begin{array}{l}\text { zaprawianie bulw/ } \\
\text { seed dressing }\end{array}$ & $\begin{array}{l}\text { skutecznie/ } \\
\text { effectively }\end{array}$ & Wainwright $\mathrm{i}$ in. (1996) \\
\hline
\end{tabular}


fungicydów podaje się także, na przykładzie fludioksonilu i mankozebu, brak mobilności stosowanych substancji aktywnych i wynikającą z tego możliwość atakowania bulw przez inokulum glebowe.

Aby ograniczyć źródła infekcji w trakcie przechowywania konieczne jest więc dezynfekowanie pomieszczeń przed załadunkiem ziemniaków oraz zaprawianie bulw przed przechowywaniem, a nawet w jego trakcie. Kutuzowa i in. (2017) wskazują, że do zaprawiania bulw w tym okresie w Rosji zarejestrowane są kwas benzoesowy, fludioksonil oraz tiabendazol. W UE do stosowania po zbiorze zatwierdzony jest tylko imazalil (rozporządzenie wykonawcze Komisji UE nr 540/2011). W USA oprócz imazalilu i tiabendazolu zezwala się także na używanie fludioksonilu, azoksystrobiny i difenokonazolu. W Polsce do zwalczania parcha srebrzystego dopuszczone jest stosowanie protiokonazolu (zaprawianie wiosenne przed i w trakcie sadzenia) oraz imazalilu (jesienią po zbiorze) - tab. 4. Jak stwierdzają Kutuzowa i in. (2017) przypadki odporności $H$. solani na wykorzystywane obecnie konwencjonalne fungicydy, wymuszają konieczność poszukiwania nowych środków do zaprawiania bulw po zbiorze. Dobrym rozwiązaniem jest według nich stosowanie fungicydu Zeroxxe opartego na koloidach srebra, który uzyskał już rejestrację w niektórych krajach Azji Południowo-Wschodniej i Ameryki Łacińskiej, a także jest w trakcie rejestracji w Rosji.

Wraz z rosnącymi obawami dotyczącymi odporności na fungicydy oraz zwiększającą się świadomością społeczną dotyczącą pośredniego i kumulacyjnego wpływu fungicydów na środowisko i zdrowie ludzi idea ograniczania stosowania fungicydów syntetycznych $\mathrm{w}$ rolnictwie staje się coraz ważniejsza i coraz powszechniej wprowadzana. W tym kontekście inne związki chemiczne, w tym sole, środki dezynfekujące i roślinne olejki eteryczne są testowane jako alternatywa do zastąpienia syntetycznych fungicydów stosowanych do zwalczania parcha srebrzystego (Avis i in. 2010).

Poszukując skutecznych substancji mogących zastąpić syntetyczne fungicydy badano chlor i dwutlenek chloru (Hervieux i in. 2002), wykorzystywano także po zbiorach roślinne olejki eteryczne. Frazier i in. (2006) wykazali, że wielokrotne stosowanie olejku goździkowego skutecznie hamuje rozwój choroby na bulwach. Podobne wyniki uzyskała Bång (2007) testując olejki eteryczne z czosnku i szałwii.

Spośród dostępnych na rynku biopestycydów Johnson (2007) badał Serenade ASO (preparat Bacillus subtilis) wykazując, że użycie tego środka obniżyło nasilenie choroby i o 5 miesięcy opóźniło jej pojawienie się w trakcie przechowywania. W USA zarejestrowano inne biopestycydy wykorzystujące szczepy Pseudomonas syringe do stosowania po zbiorze bulw (Stockwell i Stack 2007).

Zwalczanie parcha srebrzystego jest prowadzone głównie przy zastosowaniu metod agrotechnicznych (zdrowy sadzeniak, optymalny termin sadzenia, zbiór po dojrzeniu skórki, przygotowanie do przechowywania i przechowywanie). Ze względu na cykl rozwojowy patogena, a zwłaszcza jego intensywny rozwój $w$ trakcie przechowywania metody te nie są w stanie skutecznie zabezpieczyć zebrane bulwy przed infekcją. Ważnym elementem w strategii zwalczania parcha srebrzystego staje się więc zastosowanie fungicydów. Obecnie do jego zwalczania w Europie dopuszczona jest tylko 1 substancja czynna - imazalil, w Polsce dopuszcza się także stosowanie protiokonazolu. Nie jest to ilość pozwalająca na skuteczne zwalczanie tej choroby zwłaszcza w okresie jej intensywnego rozwoju podczas przechowywania. Poszukiwanie nowych substancji mogących ograniczać szkodliwość parcha srebrzystego nie tylko wśród syntetycznych fungicydów, ale także wśród substancji pochodzenia roślinnego i biologicznego może być korzystnym rozwiązaniem dla ludzi i środowiska.

Można stwierdzić, że skuteczne zwalczanie parcha srebrzystego będzie zależało od wspólnych działań producentów ziemniaka, przemysłu i naukowców oraz promowania integrowanej strategii ochrony łączącej wszystkie dostępne metody i środki w celu skutecznego i zrównoważonego zwalczania choroby. 


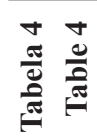

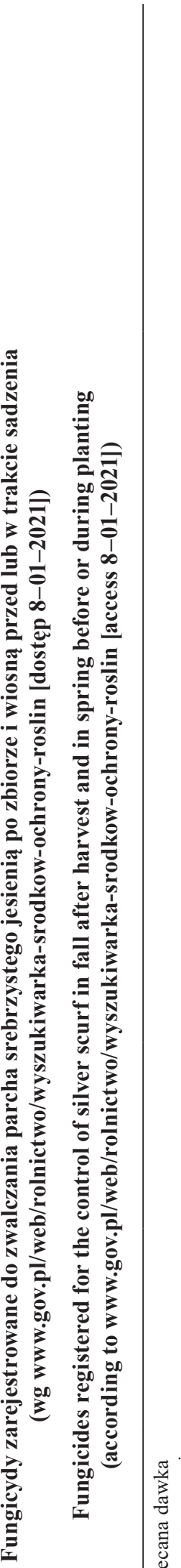

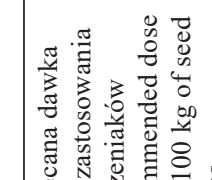

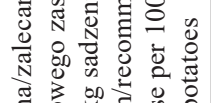

记

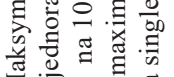

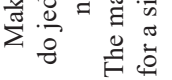

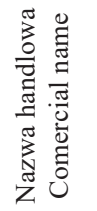

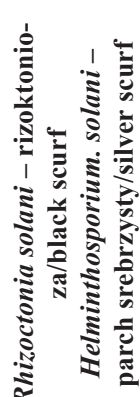

告

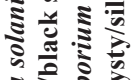

ำ

ญ

กิ

กั จิ

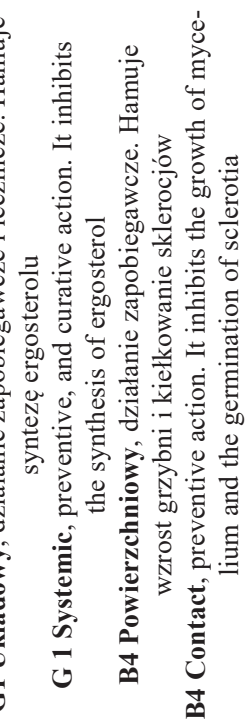

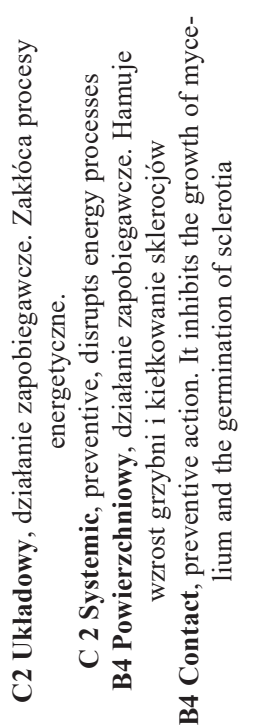

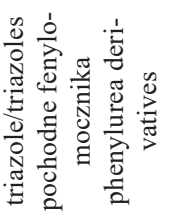

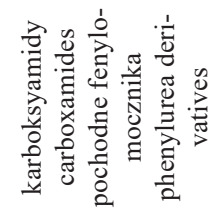

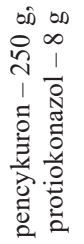

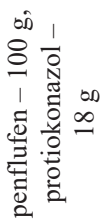

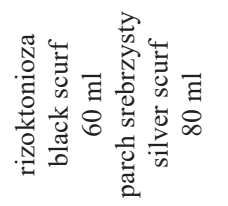

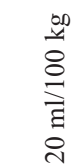

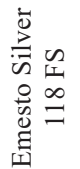

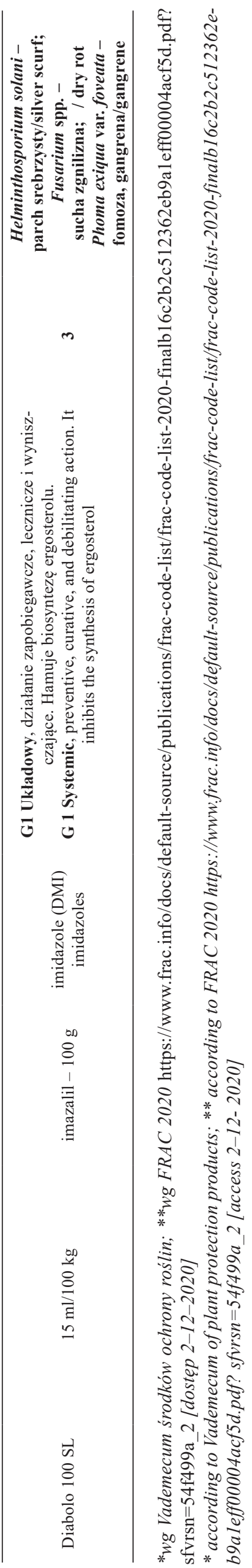




\section{Literatura}

Adams A., Sander N., Nelson D.C., 1970. Some properties of soils affecting russet scab and silver scurf of potatoes. American Potato Journal 47: 49 - 57.

Adams M.J., Hide G.A. 1980. Relationships between disease levels on seed tubers on crops during growth and in stored potatoes. 5. Seed stocks grown at Rothamsted. Potato Res. 23: $291-302$.

Adams M.J., Read P.J., Lapwood D.H., Cayle G.R., Hide G.A. 1987. The effect of irrigation on powdery scab and other tuber diseases of potatoes. Annals of Applied Biology 110, $287-294$.

Avis T.J., Martinez C., Tweddel R.J. 2010. Integrated management of potato silver scurf (Helminthosporium solani). Can. J. Plant Pathol., 32 (3): 287 - 297.

Bång U. 2007. Screening of natural plant volatiles to control the potato (Solanum tuberosum) pathogens Helminthosporium solani, Fusarium solani, Phoma foveata and Rhizoctonia solani. Potato Res., 50: 185 - 203.

Bisht V.S., Bains P.S. 1995. Silver scurf of potato: disease dynamics over generations and fungicidal control in the field. Can. J. Plant Pathol., 17: 289.

Brad, D.A. Johnson, P.B. Hamm, S. James and K.A. Rykbost. 2001. Silver Scurf, an Emerging Potato Disease. Am J Potato Res 78:454

Carter M.R., Kunelius H.T., Sanderson J.B., Kimpinski J., Platt H.W., Bolinder M.A. 2003. Productivity parameters and soil health dynamics under longterm 2-year potato rotations in Atlantic Canada. Soil Till. Res., 72: 153-168.

Cayley G.R., Hide G.A., Read P.J., Dunne Y. 1983. Treatment of potato seed and ware tubers with imazalil and thiabendazole for control of silver scurf and other storage diseases. Potato Res., 26: 163 - 173.

Charakterystyka Krajowego Rejestru Odmian Ziemniaka (2020). Red. nauk. W. Nowacki IHAR-PIB Oddz. Jadwisin s 44.

Collet-Elimane R., Jouan B. 1993. Étude de possibilités de traitement contre l'Helminthosporium solani agent de la gale argentée de la pomme de terre. In: Proceedings of the 12th Triennal Conference of the European Association for Potato Research, Paris, July 18 - 23, 1993: 485 - 486.

Cooke L.R., Little G. 1995. Evaluation of fungicidal seed tuber treatments on progeny tuber infection. Tests of Agrochemicals and Cultivars. 16. Ann. Appl. Biol., 126: $26-27$.

Copeland R.B., Logan N.C. 1975. Control of tuber diseases, especially gangrene, with benomyl, thiabendazole and other fungicides. Potato Res., 18: $179-188$.

Cunha M.G. Rizzo D.M. 2003. Development of Fungicide Cross Resistance in Helminthosporium solani Populations from California. Plant Disease v.87 (7): 798 - 803.

Cunha M.G., Rizzo D.M. 2004. Occurrence and epidemiological aspects of potato silver scurf in California. Horticultura
Brasileira, Brasília, v.22 (4): 690 - 695.

Cunnington A. C., Gray D., Ross D.W., Stroud G.P., Peters J.C. 2002. Quality demands for pre-packing. [In] Abstr. $15^{\text {th }}$ Conf. EAPR. Hamburg, The Germany 14-19 July s. 223.

Czerko Z. 2016. Technika i technologia przechowywania ziemniaków. Monografie i rozprawy naukowe 50/2016 IHAR-PIB Radzików: ss 135.

Denner F.D.N., Millard C., Geldenhuys A., Wehner F.C. 1997. Treatment of sedd potatoes with prochloraz for simultaneous control of silver scurf and black dot on progeny tubers. Potato Res., 40: 221 - 227.

Dzwonkowski W., Szczepaniak I., Zdziarska T. 2019. Popyt na ziemniaki. [W:] Rynek Ziemniaka stan i perspektywy (red. nauk. W. Dzwonkowski). IERiGŻ-PIB Warszawa 46: $20-26$.

European Commission, 2011. EU Commission implementing regulation No. 540/2011: http://eur-lex. europa.eu/LexUriServ/LexUriServ.do? uri=OJ: L:2011:153:0001:0186:EN: PDF [dostęp 9-01-2021]

Errampali D., Saunders J.M., Holley J.D. 2001. Emergence of silver scurf (Helminthosporium solani) as an economically important disease of potato. Plant. Pathol., 50: $141-153$.

Firman D. M., Allen E. J. 1993. Effects of windrowing, irrigation and defoliation of potatoes on silver scurf

(Helminthosporium solani) disease. Journal of Agricultural Science, Cambridge 121: 47 - 53.

Firman D.M., Allen E.J., 1995a. Effects of seed size, planting pattern on the severity of silver scurf (Helminthosporium solani) and black scurf (Rhizoctonia solani) diseases of potatoes. Annals of Applied Biology 127: 73 - 85.

Firman D.M., Allen E.J. 1995b. Transmission of Helminthosporium solani from potato seed tubers and effects of soil conditions, seed inoculum and seed physiology on silver scurf disease. J. Agr. Sci., 124: 219-234.

Frac code list. 2020. https://www.frac.info/docs/defaultsource/publications/frac-code-list/frac-code-list2020-finalb16c2b2c512362eb9a1 eff00004acf5d.pdf? sfvrsn=54f499a_2 [dostęp 2-12-2020]

Frazier M.J., Kleinkopf G.E., Olsen N. 2006. The effects of clove oil treatment on potato sprouting and silver scurf control. Am. J. Potato Res., 83: 110.

Frazier M.J., Shetty K.K., Kleinkopf G.E., Nolte P. 1998. Management of silver scurf (Helminthosporium solani) with fungicide seed treatments and storage practices. A. J. Potato Res., 75: 129 - 135.

Gaucher D. 1998. Gale argentée - efficacité des matičres actives. La pomme de terre française, 504: 31 - 33.

Geary B., Hamm P.B., Johnson D.A., James S.R., Rykbost K.A. 2000. Effects of fungicides and location on development of silver scurf. Am. J. Potato Res., 77: 399.

Geary B., Johnson D.A. (2006). Relationship between silver 
scurf levels on seed and progeny tubers from successive generations of potato seed. Am. J. Potato Res., 83, 447 -453 .

Geary B., Johnson D.A., Hamm P.B., James S.R., Rykbost K.A. 2007. Potato Silver Scurf Affected by Tuber Seed Treatments and Locations and Occurrence of Fungicide Resistant Isolates of Helminthosporium solani. Plant Dis., 91: $315-320$.

Hall S.M., Hide G.A. 1992. Fungicide treatment of seed tubers infected with thiabendazole resistant Helminthosporium solani and Polyscytalum pustulans for controlling silver scurf and skin spot on stored progeny tubers. Potato Res., 35: $143-147$.

Hardy C.E., Burgess P.J., Pringle R.T. 1997. The effect of condensation on sporulation of Helminthosporium solani on potato tubers infected with silver scurf and held in simulated storage conditions. Potato Research 40: 169 -180 .

Harz I. 1871. Spondylocladium atrovirens. Bulletin of Society Imperial, Moscow, 44: 42.

Hervieux V., Chabot R., Arul J., Tweddell R.J. 2001 Evaluation of different fungicides applied as seed tuber treatments for the control of potato silver scurf. Phytoprotection, 82: $41-48$.

Hervieux V., Yaganza E.S., Arul, J., Tweddell R.J. 2002. Effect of Organic and Inorganic Salts on the Development of Helminthosporium solani, the Causal Agent of Potato Silver Scurf. Plant Dis., 86,: 1014-1018.

Hide G.A., Boorer R.K.J., Hall S.M. 1994a Controlling potato tuber blemish diseases on $\mathrm{cv}$. Estimate with chemical and non-chemical methods. Ann. Appl. Biol., 124: 253 265.

Hide G.A., Boorer K.J., Hall S.M. 1994b. Effects of watering potato plants before harvest and of curing conditions on development of tuber diseases during storage. Potato Research 37: 169 - 172.

Hide G.A., Hall S.M., Boorer K.J. 1988. Resistance to thiabendazole in isolates of Helminthosporium solani, the cause of silver scurf disease of potatoes. Plant Pathol., 37: 377 -380 .

Hide G.A., Read P.J., Sandison J.P., Hall S.M. 1987. Control of potato diseases with fungicides applied to seed tubers. Tests of Agrochemicals and Cultivars, 8. Ann. Appl. Biol., 110: $72-73$.

Holley J.D., Kawchuk L.M. 1996. Distribution of thiabendazole and thiophanate-methyl resistant strains of Helminthosporium solani and Fusarium sambucinum in Alberta potato storages. Can. Plant Dis. Surv., 76: 21 -27 .

Jellis G. J., Taylor G. S. 1977. Control of silver scurf (Helminthosporium solani) disease of potato with benomyl and thiabendazole. Ann. Appl. Biol. 86: 59 - 67.

Johnson S.B. 2007. Evaluation of a Biological Agent for Control of Helminthosporium solani. Plant Pathol. J.,
6: $99-101$.

Johnson D.A., Hamm P.B., Miller J., Olsen. 2014. Managing Silver Scurf in Potatoes

https://plantpath.wsu.edu > 2014/06 [dostęp 7.12.2020]

Jouan B., Lemaire J.M., Perennec P., Sailly M. 1974. Études sur la gale argentée de la pomme de terre Helminthosporium solani Dur. Et Mont. Ann. Phytopathol., 6: 407 - 423.

Kutuzova I.A, Kokaeva L.Yu., Pobendinskaya M.A., KrutyakovYu.A., Skolotneva E.S, Chudinova E.M, Elansky S.N.2017. Resistance of Helminthosporium solani to selected fungicides applied for tuber treatment. Journal of Plant Pathology, 99 (3): 635 - 642.

Le Corre P., Bedin P., Dusson G., Salvan M. 1993. Efficacité du mancozebe dans le cadre de la lutte contre la gale argentée. In: Proceedings of the 12th Triennal Conference of the European Association for Potato Reseasch, July 18 $-23,1993: 487-488$.

Leadbeater A.J., Kirk W.W. 1992. Control of tuber borne diseases of potatoes with fenpiclonil. In: Proceedings of Brighton Crop protection Conference, Pests and Diseases, November 23 - 26, 1992: 657-662.

Lutomirska B., Szutkowska M. 2005. Wpływ gleby i wybranych zabiegów agrotechnicznych na porażenie bulw parchem srebrzystym (Helminthosporium solani). Ziemniak Polski 3: 20 - 22.

Mérida C.L., Loria R. 1990. First Report of Resistance of Helminthosporium solani to Thiabendazole in the United States. Plant Dis., 74: 614.

Mérida C.L., Loria R. 1994. Survival of Helminthosporium solani in soil and in vitro colonization of senescent plant tissue. Am. Potato J., 71, 591 - 598.

Murphy A.M., DE Jong H., Proudfoot K.G. 1999. A multiple disease resistant potato clone developed with classical breeding methodology. Can. J. Plant Pathol., 21: 207-212.

Ogilvy S.E. 1992. The use of pre-planting and postharvest fungicides and storage temperatures for the control of silver scurf in ware potatoes. Aspects Appl. Biol., 33: 151-158.

Olivier C., Halseth D.E., Mizubuti E.S.G., Loria R. 1998. Postharvest Application of Organic and Inorganic Salts fot Suppression of Silver Scurf on Potato Tubers. Plant Disease 82: 213 - 217.

Osowski J., Bernat E. 2005. Problem parcha srebrzystego na wybranych odmianach ziemniaka zarejestrowanych w Polsce. Progress in Plant Protection/Postępy w Ochronie Roślin: 336-341.

Osowski J. 2019. Choroby skórki bulw ziemniaka - występowanie, objawy i sposoby zwalczania. Ziemniak Polski 1: $33-42$.

Pasche J.S., Piche L.M., Gudmestad N.C., 2005. Effect of the F129L Mutation in Alternaria solani on Fungicides Affecting Mitochondrial Respiration. Plant Disease 89: $269-278$.

Peters R.D., Surz A.V., Carter M.R., Sanderson J.B. 2003. 
Developing disease-suppressive soils through crop rotation and tillage management practices. Soil Till. Res., 72: 181-192.

Pobedinskaya M.A., Plutalov P.N., Romanova S.S., Kokaeva L.Y., Nikolaev A.V., Alexandrova A.V., Elansky S.N., 2012. Resistance of potato and tomato early blight pathogens to fungicides. Mikologiya I Fitopatologiya 46: 402 -408 .

Poradnik sygnalizatora ochrony ziemniaka. 2016. Opr. zbior. pod red. A. Wójtowicza i M. Mrówczyńskiego. IOR-PIB Poznań: $52-58$.

Pringle R.T., Hardy C.H., Clayton R., McGovern R., Potter K. 1998. Chemical free storage of potatoes. Scottish Agricultural College Information Bulletin, Aberdeen, UK: SAC, $1-3$.

Read P.J., Storey R.M.J., Hudson D.R. 1995. A survey of black dot and other fungal tuber blemishing diseases in British potato crops at harvest. Ann. of Appl. Biol., 126: 249 258.

Rębarz K. 2018. Choroby grzybowe. [W:] Ziemniak identyfikacja agrofagów oraz niedoborów pokarmowych. Agro Wydawnictwo, Suchy Las: 128 - 168.

Rodriguez D.A., Secor G.A., Gudmestad N.C., Francl L.J. 1996. Sporulation of Helminthosporium solani and Infection of Potato Tubers in Seed and Commercial Storages. Plant Disease 80: 1063 - 1070.

Secor G.A., Gudmestad N.C. 1999. Managing fungal diseases of potato. Can. J. Plant Pathol., 21: 213 - 221.

Shetty K.K., Frazier M.J., Kleinkopf G.E. 1994. Recent research information on silver scurf control under Idaho potato production and storage conditions. 26th Annual Idaho potato School: $191-194$.

Stevenson W.R., Loria R., Franc G.D., Weingartner D.P. 2001. Compendium of Potato Diseases (2nd ed.). St. Pail, MN: APS Press.

Stockwell V.O., Stack J.P. 2007. Using Pseudomonas spp. for integrated biological control. Phytopathology, 97: 244 -249 .

Śnieg L. 1992. Effectiveness of liming at selected stages of crop rotation. 1. Effect of liming at different stages of the rotation on tuber yield and infection with common scab and silver scab in four potato cultivars. Zeszyty
Naukowe Akademii Rolniczej w Szczecinie, Rolnictwo 52: $127-132$.

Tian S.M., Chen Y.C., Zou M.Q., Xue Q. 2007. First report of Helminthosporiun solani causing silver scurf of potato in Hebei Province, North China. Plant Dis., 91: 460.

Tsror L., Peretz-Alon I. 2002. Reduction of silver scurf on potatoes by pre- and post-storage treatment of seed tubers with imazalil. Am. J. Potato Res., 79, 33-37.

Tsror L., Peretz-Alon I. 2004. Control of silver on potato by dusting or spraing seed tubers with fungicides before planting. Am. J. Potato Res., 81: 291 - 294.

Vademecum środków ochrony roślin. 2017. Opracowanie zbiorowe. Red. nauk. M. Korbas, A. Paradowski, P. Węgorek. Wyd. Agronom ss 672.

Wainwright A., Nicholson T., Mann D.H. 1996. Control of silver scurf and black scurf in potatoes with a pencycuron/tolylfluanid seed tuber treatment. In: proceedings of Brighton Crop Protection Conference, Pests and Diseases, November 18 - 21, 1996: 275 - 280. Farnham, UK: British Crop Protection Council.

Wale S., Platt H.W., Cattlin N. 2008. Fungal and fungal like diseases. [W:] Diseases, pests and disorders of potatoes. Manson Publishing Ltd: 28-70.

Weber Z. 2011a. Parch srebrzysty ziemniaka. [W:] Fitopatologia T. 2 Choroby roślin uprawnych. Red. nauk. S. Kryczyński, Z. Weber. PWRiL Poznań 2011: 317.

Weber Z. 2011b. Choroby powodowane przez grzyby z typu Ascomycota (workowce) [W:] Fitopatologia T 2 Choroby roślin uprawnych. Red. nauk. S Kryczyński, Z Weber. PWRiL Poznań 2011: 288 - 289.

Welsh R.D. 1996. Evaluation of fenpiclonil as a potato seed tuber treatment for the control of Rhizoctonia solani and Helminthosporium solani. In: Proceedings of the 49th New Zealand Plant Protection Conference, August 13 15, 1996: 152 - 156. Nelson, New Zealand: New Zealand Plant Protection Society.

Wnękowski S., Błaszczak W. 1997. Choroby ziemniaka [W:] Ochrona Roślin Red. nauk. Kochman J., Węgorek W. Plantpress, Kraków 1997: 505 - 535.

www.gov.pl/web/rolnictwo/wyszukiwarka-srodkow-ochrony -roslin [dostęp 8-01-2021]) 